\title{
Effect of $\mathrm{GA}_{3}$, IAA and their mixtures on the formation and development of cell systems in the vegetative and generative thallus of Chara vulgaris $\mathbf{L}$.
}

MARIA KWIATKOWSKA*, ALEKSANDRA GOSEK*, MIROSLAW GODLEWSKI**

Department of Cytophysiology*, and Department of Plant Cytology and Cytochemistry**, Institute of Physiology and Cytology, University of Łódź, Banacha 12/16, PL-90-237 Łódź, Poland

(Received: May 14, 1990. Accepted: October 5, 1990)

\begin{abstract}
In concentrations ranging from $10^{-7}$ to $10^{-5} \mathrm{M}$ IAA strongly stimulates the growth of the main axis and pleuridia internodal cells, while it does not affect the number of lateral branches and generative organs. In the higher concentrations it reduces the number of spermatozoids in the antheridium. In the same concentration range, $\mathrm{GA}_{3}$ inhibits the growth of the main axis and pleuridia internodal cells, does not affect the number of lateral branches, increases the number of antheridia and increases the number of forming spermatozoids.

Incubation in mixture of both regulators has shown that: a) IAA eliminates the inhibitory effect of $\mathrm{GA}_{3}$ on the growth of internodal cells of the main axis and its stimulatory action is slightly weakened by $\mathrm{GA}_{3}$, b) IAA in a concentration of $10^{-5} \mathrm{M}$ along with a low concentration of $\mathrm{GA}_{3}\left(10^{-7}\right)$ increases the number of main axis lateral branches.

The conclusion is drawn that the growth of the vegetative part of the thallus is more intense when auxin predominates, but generative development requires a high level of gibberellin.
\end{abstract}

Key words: $G A_{3}, I A A$, morphogenesis, Chara vulgaris $L$.

\section{INTRODUCTION}

Studies of the influence of some growth substances on algae were initiated by Yin in 1937 (C o n r a d and S a $1 \mathrm{tm}$ a $\mathrm{n}$ 1962) on the role of IAA on cell size in Chlorella vulgaris. J a h $\mathrm{n}$ ke and L i b be r t (1964) demonstrated the presence of IAA in the thallus of Chara sp. Different extraction procedures and detection methods were used to show that IAA was present in the thallus of Caulerpa paspaloides ( $\mathrm{J}$ a c o b s et al. 1985). Gibberellin-like substanes were found in thalli of Chara sp. (M u r a k a m i 1966) and in many other groups of algae (R a d le y 1961, Mowat 1963, Jennings and McComb 1967, Gupta and Argaval 1973). This fact promoted investigations on their role in life processes in algae. 
The culture of Chara vulgaris in an artificial medium became a particulary convenient model for studies on the influence of hormones on plant development. The thallus of Chara vulgaris grows by successive mitotic division of the apical cell. Two cells are formed after every division: a new-apical and subapical cell ( $\mathrm{P} \mathrm{i} \mathrm{c} \mathrm{k} \mathrm{e} \mathrm{t} \mathrm{t}-\mathrm{H}$ e a p s 1967a). The subapical cell divides once more and forms two sister-cells: the upper cell - which organizes the haploidal node, and the basal cell — which forms the internode ( $\mathrm{D} \mathrm{u} \mathrm{c} \mathrm{r} \mathrm{e} \mathrm{u} \mathrm{x} \mathrm{1968).} \mathrm{The} \mathrm{internodal} \mathrm{cell}$ nucleus becomes polyploid ( $\mathrm{S}$ h e $\mathrm{n}$ 1967a) and after amitotic fragmentation, the internodes are made up of multinuclear cells ( $\mathrm{S}$ h e $\mathrm{n}$ 1967b). The nodes initiate the development of lateral pleuridia which consist of nodes and internodes. The cells of the pleuridial nodes undergo mitotic divisions and form the generative organs: antheridia and oogonia.

Earlier complex investigations have shown that $\mathrm{GA}_{3}$ accelerates the development of generative organs i.e. the oogonia and antheridia. $\mathrm{GA}_{3}$ was also found to increase the number of spermatozoids produced in the antheridia ( G o d lew s k i and K w i a t k ow s k a 1980). Inhibition of the elongation of internodes in the main axis and pleuridia of the thallus was observed simultaneously. Decreasing the level of endogenous gibberellins by AMO-1618 stimulated the elongation of the thallus (K wiat k ow sk a and Godlew ski 1980).

Autoradiographic and cytochemical investigations of successive cell cycles of antheridial filaments preceding formation of spermatozoids have shown that $\mathrm{GA}_{3}$ accelerates the course of all phases of interphase ( $\mathrm{G}$ o d l e w s k i 1977). However, a high level of auxin is necessary for initiation of mitosis ( $\mathrm{G} \mathrm{o} \mathrm{d} \mathrm{le} \mathrm{w} \mathrm{s} \mathrm{k} \mathrm{i} \mathrm{1980).}$ IAA $\left(10^{-5} \mathrm{M}\right)$ shortened the duration of $\mathrm{G} 2$ phase and mitosis, while PCIB $\left(10^{-5}\right.$ M) caused their prolongation and a fall in mitotic activity. Simultaneously IAA reduced the number of spermatozoids produced in the antheridium resulting from a decrease in the number of divisions in the first stage of spermatogenesis (Godlewski 1980). The effect of IAA on this process is opposite to that caused by exogenous $\mathrm{GA}_{3}$ (Godlewski and K wiatkowska 1980) and similar to the effect of AMO-1618 (K w i a t k ow s k a and G od lew s k i 1988).

The aim of the present investigation was: 1) to compare the individual influence of IAA and $\mathrm{GA}_{3}$ on the development of the vegetative part of the thallus and generative organs formed on it; 2) to investigate the way in which IAA and $\mathrm{GA}_{3}$ used simultaneously modifiy the development of the Chara thallus. Interactions between these hormones in the regulation of developmental processes were noticed in many publications (F.e. N a i r et al. 1979, M a h e s h w a ri et al. 1980, A d a m s and Ross 1983, Law and Hamilton 1984, and ref. Cleland 1969).

\section{MATERIAL AND METHODS}

The apical parts of Chara vulgaris $\mathrm{L}$. thalli used in the experiments were cultivated in For s berg's medium (1965) in Nessler's tubes under artificial illumination with a natural photoperiod $(\mathrm{L}: \mathrm{D}=14: 10)$ for 21 days. Five-nodal 
parts of thalli were placed in Forsberg's medium containing IAA in the following concentrations: $10^{-5}, 10^{-6}, 10^{-7} \mathrm{M}$; $\mathrm{GA}_{3}$ in concentrations: $10^{-5}, 10^{-6}, 10^{-7} \mathrm{M}$ and mixtures of these regulators in the following variants: IAA $10^{-5}+\mathrm{GA}_{3} 10^{-5} \mathrm{M}$, IAA $10^{-5}+\mathrm{GA}_{3} 10^{-7} \mathrm{M}$ and IAA $10^{-7}+\mathrm{GA}_{3} 10^{-7} \mathrm{M}$.

The appearance of new nodes, lateral branches and rhizoids on the main axis, the opening of antheridia with liberation of spermatozoids and maturation of oogonia with transformation into brownish oospores were observed during the experiment.

The length of the main axis, internodes and pleuridia were measured using photographs of the plants at the start and at the end of the experiment.

After 21 days the plants were fixed in an ethanol-acetic acid mixture $(3: 1, v / v)$. Isolated antheridia were stained with acetic carmine and squashed on slides for estimation of the number of filaments and number spermatids in the filaments and the antheridium.

The results were analysed statistically. Standard error (SE) and significance of differences using Student's test at $\mathrm{p}=0.05$ were calculated.

\section{RESULTS}

THE LENGTH OF AXIAL INTERNODES

The lenght of internodes was measured as the difference between the length at the start and at the end of the experiment, taken from photographes (Fig. 1). The internodes were numbered from the oldest (I) to the youngest (VIII). Internode V

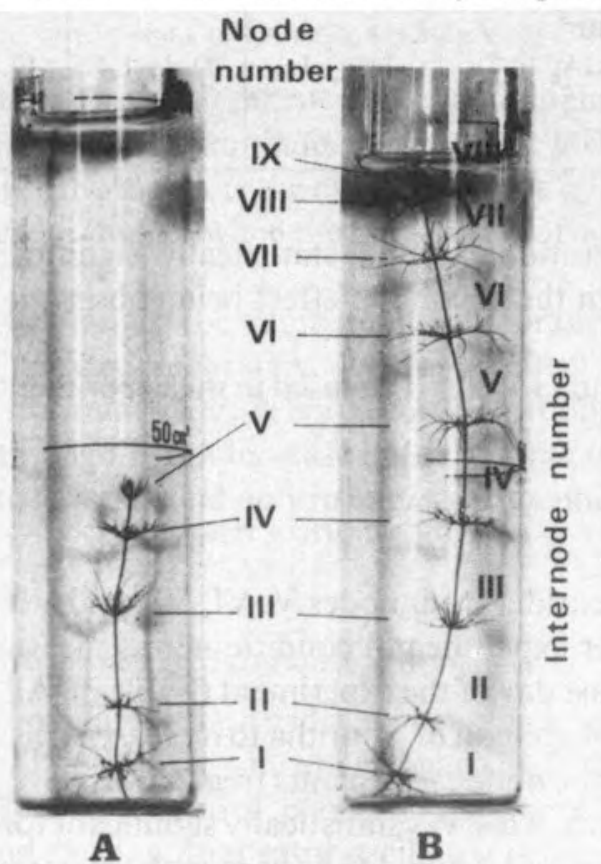

Fig. 1. Apical fragment of Chara w whars thallus. A - at the start of the experiment, B - after 21 days of cultivation 
had already been formed before the administration of hormones and was in the course of development during the experiment. Internodes VI, VII and VIII were formed and developed during the experiment. The maximum effect on elongation was observed on internodes V, VI and VII.

Internodes treated with IAA were longer than control cells, but this was statistically significant only in V and VI at a concentration of $10^{-7} \mathrm{M}$ (Table 1).

Table 1

Increases in the length of axial internodes after treatment with IAA, $\mathrm{GA}_{3}$ and their mixtures

\begin{tabular}{|c|c|c|c|}
\hline \multirow{2}{*}{$\begin{array}{l}\text { Experimental } \\
\text { variant }\end{array}$} & \multicolumn{3}{|c|}{ No of internodes } \\
\hline & V & VI & VII \\
\hline Control & $10.3 \pm 1.0$ & $12.1 \pm 1.0$ & $9.5 \pm 0.9$ \\
\hline IAA $10^{-5} \mathrm{M}$ & $11.6 \pm 1.0$ & $13.5 \pm 1.2$ & $12.1 \pm 2.0$ \\
\hline $10^{-6} \mathrm{M}$ & $12.8 \pm 1.3$ & $11.8 \pm 0.9$ & $9.5 \pm 1.3$ \\
\hline $10^{-7} \mathrm{M}$ & $13.4 \pm 1.2$ & $14.1 \pm 1.0$ & $11.6 \pm 1.4$ \\
\hline $\mathrm{GA}_{3} 10^{-5} \cdot \mathrm{M}$ & $8.4 \pm 0.6$ & $9.2 \pm 0.6$ & $5.9 \pm 0.7$ \\
\hline $10^{-6} \mathrm{M}$ & $6.6 \pm 0.5$ & $5.4 \pm 0.3$ & $2.2 \pm 0.3$ \\
\hline $10^{-7} \mathrm{M}$ & $8.7 \pm 0.5$ & $9.6 \pm 0.5$ & $7.3 \pm 0.9$ \\
\hline IAA $10^{-5}$ & & & \\
\hline $\begin{array}{r}+\underset{\mathrm{GA}_{3}}{ } 10^{-5} \mathrm{M} \\
\mathrm{IAA} 10^{-5^{3}}\end{array}$ & $11.8 \pm 1.4$ & $15.4 \pm 1.0$ & $12.7 \pm 1.4$ \\
\hline $\begin{array}{r}+\mathrm{GA}_{3} 10^{-7} \\
\text { IAA } 10^{-7^{3}}\end{array}$ & $11.1 \pm 1.2$ & $11.8 \pm 1.4$ & $10.2 \pm 1.5$ \\
\hline$+\mathrm{GA}_{3} 10^{-7} \mathrm{M}$ & $11.1 \pm 1.4$ & $12.5 \pm 1.5$ & $10.9 \pm 1.7$ \\
\hline
\end{tabular}

$\mathrm{GA}_{3}$ in all concentrations caused statistically significant shortening of the internode length with the maximum effect being observed at a concentration of $10^{-6} \mathrm{M}$.

All of the IAA and $\mathrm{GA}_{3}$ mixtures used in the experiments increased the length of internodal cells.

\section{THE LENGTH OF PLEURIDIA}

The length of pleuridia from nodes V, VI, VII and VIII, which were formed and developed under experimental conditions was measured from the photographs taken on the last day of the experiment (Table 2). All of the concentrations of used IAA caused the length of pleuridia to increase. This effect was statistically significant for all of the nodes. The plants treated with $\mathrm{GA}_{3}$ had shorter pleuridia than the control plants. This was statistically significant for nodes V, VI and VII.

All of the mixtures of IAA and $\mathrm{GA}_{3}$ used in the experiment caused a marked increase in the length of pleuridia as compared with controls, but their length did 
Table 2

The length of pleuridia after treatment with IAA, $\mathrm{GA}_{3}$ and their mixtures

\begin{tabular}{|c|c|r|r|r|}
\hline \multirow{2}{*}{$\begin{array}{c}\text { Experimental } \\
\text { variants }\end{array}$} & \multicolumn{4}{|c|}{ No of node } \\
\cline { 2 - 5 } & $\mathrm{V}$ & \multicolumn{1}{|c|}{ VI } & \multicolumn{1}{c|}{ VII } & \multicolumn{1}{c|}{ VIII } \\
\hline Control & $5.6 \pm 0.8$ & $5.0 \pm 0.2$ & $6.0 \pm 0.6$ & $5.7 \pm 0.6$ \\
IAA $10^{-5} \mathrm{M}$ & $8.9 \pm 1.3$ & $10.6 \pm 1.2$ & $11.8 \pm 1.1$ & $10.3 \pm 1.4$ \\
$10^{-6} \mathrm{M}$ & $7.5 \pm 0.8$ & $10.3 \pm 0.6$ & $10.3 \pm 0.7$ & $8.6 \pm 0.7$ \\
$10^{-7} \mathrm{M}$ & $8.2 \pm 1.1$ & $9.7 \pm 1.1$ & $12.8 \pm 0.7$ & $11.0 \pm 0.7$ \\
$\mathrm{GA}_{3} 10^{-5} \mathrm{M}$ & $4.3 \pm 0.3$ & $4.0 \pm 0.3$ & $4.7 \pm 0.4$ & $4.9 \pm 0.5$ \\
$10^{-6} \mathrm{M}$ & $4.2 \pm 0.2$ & $4.7 \pm 0.2$ & $5.0 \pm 0.2$ & $5.3 \pm 0.4$ \\
$10^{-7} \mathrm{M}$ & $4.5 \pm 0.2$ & $4.3 \pm 0.3$ & $4.8 \pm 0.3$ & $4.9 \pm 0.4$ \\
$\mathrm{IAA} 10^{-5}$ & $7.3 \pm 0.5$ & $8.8 \pm 1.1$ & $10.5 \pm 1.1$ & $9.6 \pm 1.0$ \\
$+\mathrm{GA}_{3} 10^{-5} \mathrm{M}$ & & & & \\
IAA $10^{-5}$ & $8.2 \pm 0.7$ & $9.2 \pm 1.0$ & $11.1 \pm 0.9$ & $9.3 \pm 1.2$ \\
$+\mathrm{GA}_{3} 10^{-7} \mathrm{M}$ & & & & \\
IAA $10^{-7}$ & & & & \\
$+\mathrm{GA}_{3} 10^{-7} \mathrm{M}$ & $8.4 \pm 1.1$ & $9.9 \pm 0.7$ & $11.3 \pm 1.2$ & $9.4 \pm 1.4$ \\
\hline
\end{tabular}

not exceed that after treatment with IAA. The maximum statistically significant effect was observed in the variant where both hormones were in equal concentrations of $10^{-7} \mathrm{M}$.

\section{THE NUMBER OF LATERAL BRANCHES}

The buds which initiate the development of lateral branches and rhizoids are formed at a certain distance from the thallus apex at the base of the pleuridia. This distance is the longer the higher is the elongation rate of the main axis. The number of lateral branches is higher when the breakdown of apical domination is more effective.

Neither IAA nor $\mathrm{GA}_{3}$ changed the number of lateral branches to a statistically significant extent if applied separately. A similar effect was observed for mixtures in which both hormones were in equal concentrations i.e. $10^{-5} \mathrm{M}$ or $10^{-7}$ M. (Fig. 2). A statistically significant increase in the number of lateral branches, from 2.5 in the control to 4 , was found only in one experimental variant: IAA $10^{-5}$ $+\mathrm{GA}_{3} 10^{-7} \mathrm{M}$ (Fig. 2).

\section{THE NUMBER OF ANTHERIDIA AND OOGONIA}

In Chara the development of antheridia and oogonia is initiated at early stages of formation of pleuridia in apical parts of the thallus ( $\mathrm{Pic}$ ket t-Heaps 1967b). In the control plants, the number of antheridia and oogonia was similar and their mutual ratio oscillated around 1.0. 

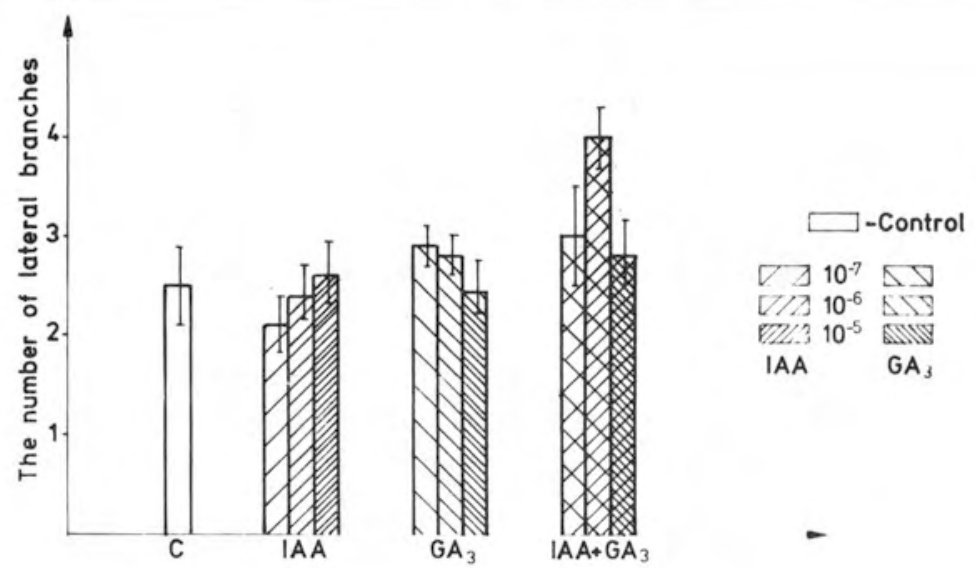

Fig. 2. The number of lateral branches of the inam axis lormed after treatment wah $1 . \backslash, \bigcup_{3}$ and their mixtures

IAA did not change the number of antheridia (Fig. 3b) or oogonia (Fig. 3a) in any of the experimental concentrations. The investigations with $\mathrm{GA}_{3}$ showed that the optimum concentration of this hormone for production of antheridia was $10^{-6} \mathrm{M}$ (a statistically significant increase) (Fig. 3b). A similar effect (but not as strong and statistically unsignificant) was observed for oogonia (Fig. 3a). In concentrations of $10^{-6}$ and $10^{-5} \mathrm{M}$ the antheridia-oogonia ratio was higher than in the control.

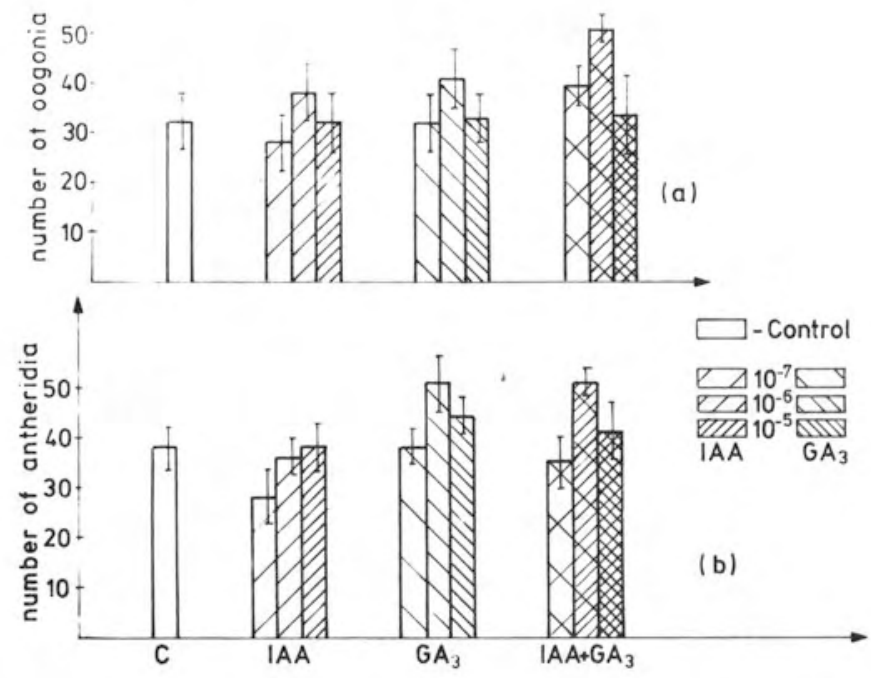

Fig. 3. The number of oogonia (a) and antheridia (b) after action of IAA, GA 3 and their mixtures 
The greatest increase in the number of generative organs formed on Chara thalli after treatment with IAA and $\mathrm{GA}_{3}$ mixtures was found in the variant with $\mathrm{GA}_{3}$ in concentrations of $10^{-7} \mathrm{M}$ and IAA $10^{-5} \mathrm{M}$. This effect was noticed both for antheridia and oogonia, so their mutual ratio remained at the same level (Fig. 3a and $b)$.

\section{THE PRODUCTIVITY OF AN ANTHERIDIUM}

The biological productivity of an antheridium is defined by the number of spermatozoids developing within an antheridium. This parameter depends on two processes: 1) the mitotic activity of capitular cells and 2) the number of cellular divisions within the filaments. The first process determines the number of antheridial filaments, the second one - the number of cells in one filament which are transformed into spermatozoids.

The highest concentration $\left(10^{-5} \mathrm{M}\right)$ of IAA caused a significant reduction of the number of spermatozoids inside the antheridium. The other variants did not modify this parameter. The opposite effect was observed for $\mathrm{GA}_{3}$, i.e. the highest productivity of the antheridia was found at the concentrtions of $10^{-6}$ and $10^{-7}$ M (Fig. 4).

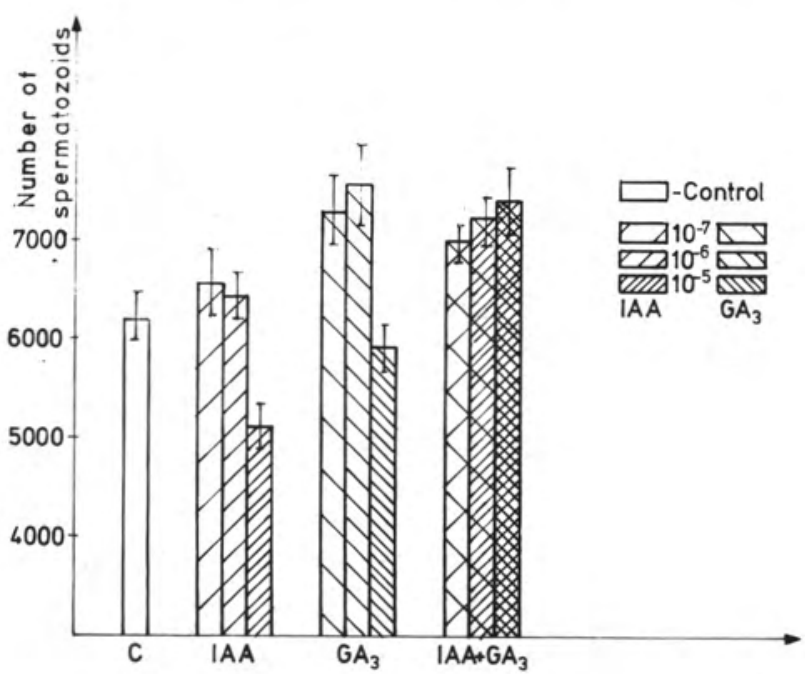

Fig. 4. The number of spermatozoids in antheridia alter treatment whth $\mathrm{IAA}, \mathrm{GA}_{3}$ and their mixtures

All of the mixtures of IAA and $\mathrm{GA}_{3}$ used in this experiment caused a statistically significant increase in the number of spermatozoids per antheridium from about 6200 in the control to $7000-7400$ depending on the variant. The strongest influence was noticed for IAA $10^{-5}+\mathrm{GA}_{3} 10^{-5} \mathrm{M}$ (Fig. 4). 


\section{DURATION OF SPERMATOGENSIS}

Spermatogenesis is considered to last from the appearance of initial cells of the antheridial filaments up to the formation and liberation of mature spermatozoids and disintegration of the antheridium. In all of the experimental concentrations, IAA caused significant prolongation of the duration of spermatogensis (Fig. 5). After treatment with $\mathrm{GA}_{3}$, statistically significant reduction of the time of spermatogenesis was observed for all concentrations of this hormone.

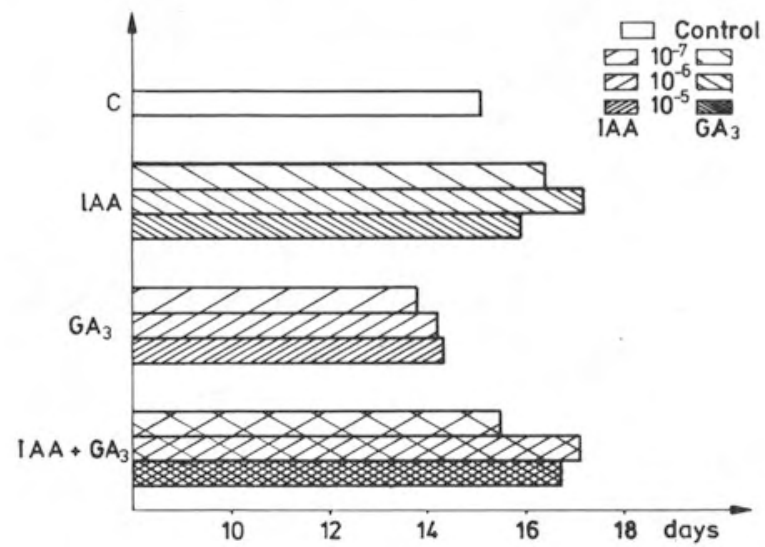

Fig. 5. The duration of spermatogenesis after treatment with IAA, GA 3 and their mixtures

All of the mixtures of IAA and $\mathrm{GA}_{3}$ used in the experiment showed similar effects as IAA, i.e. prolongation of spermatogenesis. The results obtained for all of the experimental variants were statistically significant, but the strongest effect was observed for IAA $10^{-5}+\mathrm{GA}_{3} 10^{-7} \mathrm{M}$.

\section{DISCUSSION}

As shown by results of numerous investigations, interactions between auxins and gibberellins can be very different: synergistic, additive, subadditive or antagonistic (ref. Brian 1966, Kazam a and Katsumi 1974, Jacobs 1986). The mechanisms of these processes are not well-known yet. $\mathrm{GA}_{3}$ may increase the auxin level as a result of stimulation of IAA synthesis or reduction of IAA-oxidase activity (ref. Cleland 1969, Lantican and Muir 1969, Law and Hamilt on 1984, 1989). It was found that gibberellins can also influence the basipetal transport of auxins (M a heshwari et al. 1980). In many cases, gibberellins affect elongation only in the presence of auxins. The addition of antiauxins inhibits their stimulatory effect (C le la n d 1969).

Gibberellins act in another way, unrelated to auxins, on many morphogenetic processes such as activation of the subapical meristem, flowering of short-day 
plants, sex determination (ref. Cle l a n d 1969). This action wiy be based on the expression of specific genes. The alga Caulerpa prolifera rein to $\mathrm{GA}_{3}$ added to the culture medium in a way that contrasts with its response to IAA. GA stimulates rhizome elongation and the rate of rhizoid initiation, but IAA has no effect on rhizoid regeneration and decreases their elongation $(\mathrm{J}$ a c o b s and D a vies 1983, J a c o bs 1986).

The results of the present experiments demonstrating the effect of IAA and $\mathrm{GA}_{3}$ on many morphogenetic processes in Chara vulgaris seem to show that on the level of the organism, the effects of these hormones are complementary to each other. Harmonious development of the plant as a whole and of its generative organs was observed only when the appropriate quantitative ratio of these hormones was used.

IAA caused an increase in the length of multinuclear internodes of pleuridia (Fig. 6a), but $\mathrm{GA}_{3}$ 's action on the development of the vegatative thallus was opposite to that of IAA (Figs 6a, b). In this case, the effect of $\mathrm{GA}_{3}$ cannot be attributed to an increased auxin level. In contrast to the generatively mature thallus, the immature thallus, growing from oospores reacts to increased $\mathrm{GA}_{3}$ levels by stimulation of the elongation of internodes and pleuridia ( $\mathrm{m}$ a h o r i and I w a s a 1965) and Nitella (S t a r 1 in g et al. 1974). The hypothesis was set forth that the inhibitory effect of exogenous gibberellin on the elongation of vegetative cells is the result of a supraoptimal levels of endogenous gibberellins in the generatively mature thallus (K wiat k owska and God lewski 1980).
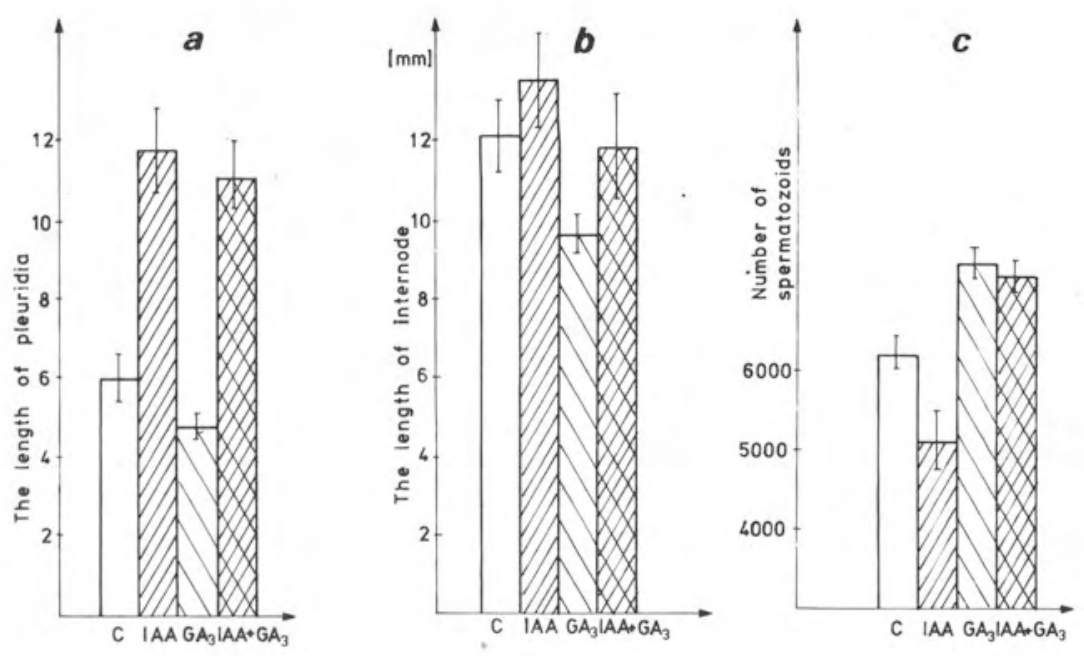

Fig. 6. A comparison of the effects of IAA $\left(10^{-5} \mathrm{M}\right), \mathrm{GA}_{3}\left(10^{-7} \mathrm{M}\right)$ and a mixture of IAA $10^{-5} \mathrm{M}+\mathrm{GA}_{3}$ $10^{-7} \mathrm{M}$ on the length of pleuridia (a), the length of internodes (b) and numbr of spermatozoids in antheridia (c) 
The effect of AMO-1618 - an inhibitor of endogenous gibberellin synthesis (Lang 1970) - which caused an increase in the length of internodes and pleuridia supports the above hypothesis. The same growth-stimulating effect on pleuridia and some of the main axis internodes was observed after simultaneous addition of $\mathrm{GA}_{3}$ and IAA, the length of pleuridia and internodes was, as a rule, the same as in the presence of only IAA (Figs 6a, b). The increase in the IAA level caused by addition of exogenous auxine seems to decrease the capacity of $\mathrm{GA}_{3}$ to reduce the elongation of multinuclear vegetative cells of Chara. We assume that the addition of gibberellin inhibits the growth of these cells as the result of disturbing the quantitative ratio between these two hormones.

The other type of vegetative cells in the Chara thallus is the apical cells of the main axis lateral resting buds. They are mononuclear and capable of mitotic divisions ( $\mathrm{D} \mathrm{u} \mathrm{c} \mathrm{r} \mathrm{e} \mathrm{u} \mathrm{x} \mathrm{1974).} \mathrm{The} \mathrm{measure} \mathrm{of} \mathrm{apical} \mathrm{cells'} \mathrm{mitotic} \mathrm{activity} \mathrm{is} \mathrm{the}$ number of nodes and internodes which appear as a result of these divisions. IAA and $\mathrm{GA}_{3}$ or mixtures of both hormones do not significantly affect these divisions. But the mitotic activity of the apical cells of resting buds is accelerated after treatment with higher concentrations of $\mathrm{GA}_{3}$ which leads to formation of more numerous lateral branches (see K w i a t k o w s k a and Go d le w s k i 1980). In contrast, IAA at a concentration of $10^{-7} \mathrm{M}$ which slightly, statistically insignificantly, increases apical domination, causes a decrease in the number of lateral branches. After treatment with a mixture of IAA and $\mathrm{GA}_{3}$, the number of lateral branches is high, which confirms the stimulatory effect of $\mathrm{GA}_{3}$ on this process.

The number of Chara antheridia does not change after $\mathrm{GA}_{3}$ treatment, but following IAA they become less numerous. Oogonia are more numerous after treatment with IAA at the concentration of $10^{-5} \mathrm{M}$ but their number is not affected by $\mathrm{GA}_{3}$. Simultaneous action of IAA and $\mathrm{GA}_{3}$ caused a harmonious increase in the number of both antheridia and oogonia. Stimulation was most intense with a mixture in which IAA was at a concentration of $10^{-5} \mathrm{M}$ and $\mathrm{GA}_{3}$ $10^{-7} \mathrm{M}$. The same mixture effectively increased the productivity of antheridia (Fig. 6c). This productivity is reduced by IAA and increases after addition of $\mathrm{GA}_{3}$. The number of spermatozoids in the antheridium is modified mainly by changes in the number of mitotic cycles in antheridial filaments ( $\mathrm{K}$ w i a t k o w sk a and Godlewski 1988).

The presented studies prove the requirement specificity of the different types of cells in the Chara thallus for the level of regulators and their mutual quantitative relations. In general, IAA or $\mathrm{GA}_{3}$ selectively stimulate some processes and do not affect or inhibit others. Frequently, the effect of IAA is opposite to that of $\mathrm{GA}_{3}$. The majority of developmental processes in all parts of the Chara thallus is stimulated by hormones when the levels of both regulators are increased.

These observations seem to confirm the earlier views of $\mathrm{Skoog}$ and Mille r (1957) that control of processes connected with growth and develop- 
ment results not only from the action of a particular hormone but from the interaction and definite balance between different kinds of plant growth substances.

\section{Acknowledgment}

This work was supported by the Polish Academy of Sciences through project CPBP. 04.01.05.

\section{REFERENCES}

A dam s P.A., Ross M.A., 1983. Interaction of indoleacetic acid and gibberellic acid in the short-term growth kinetics of oat stem segments. Plant Physiol. 73: 566-568.

B ria n P.W., 1966. The gibberellins as hormones. Int. Rev. Cytol. 19: 229-266.

Clel a n d R.E., 1969. Gibberellins. In: The physiology of plant growth and development. M.B. Wilkins ed., pp. 59-96, McGraw-Hill Publ. Comp. Ltd., London.

Con rad H.M., Saltman P., 1962. Growth substances. In: Physiology and biochemistry of algae. Academic Press.

D ucreux G., 1968. Sur l'ultrastructure des apex des bourgeons, principal et axillair de Chara vulgaris. Acad. Sci. Paris 267: 163-166.

D u c r e u x C., 1974. Influence des correlations d'inhibition sur la morphogenese de Chara vulgaris culture in vitro. Rev. Cytol. Biol. Veg. 37: 299-308.

Forsberg C., 1965. Nutritional studies of Chara axenic cultures. Plant Physiol. 18: 275-289.

Godlews k i M., 1977. The role of plant growth substances in the regulation of the cell cycle in antheridial filaments of Chara vulgaris L. I. Effect of gibberellic acid on some processes in the course of the cell cycle. Acta. Soc. Bot. Pol. 46: 317-329.

God lew s k i M., 1980. Auxin as a factor regulating initiation of mitosis in antheridial filaments of Chara vulgaris L. Biochem. Physiol. Pflanzen 175: 314-321.

Godlewski M., K wi at k owska M., 1980. Effect of gibberellic acid on the formation and development of antheridia and oogonia of Chara vulgaris L. Acta Soc. Bot. Pol. 49: 127-135.

Gupta A.B., Argaval P.R., 1973. Extraction, isolation and bioassay of gibberellin-like substances from Phormidium foreolarum. Ann. Bot. 37: 737.

I mahori K., I wasa K., 1965. Pure culture and chemical regulation of the growth of Charophytes. Phycologia 4: 127-135.

J a c o bs W.P., 1986. Are angiosperm hormones present in, and used as hormones by algae? Plant Growth Substances, ed. M. Bopp, pp. 250-256. Springer-Verlag, Berlin-Heidelberg.

J a c o b s W.P., D a v is W., 1983. Effect of gibberellic acid on the rhizome and rhizoids of the algal coenocyte, Caulerpa prolifera in culture. Ann. Bot. 52: 39-41.

J a cobs W.P., Falkenstein K., Hamilton R.H., 1985. Nature and amount of auxin in algae - IAA from extracts of Caulerpa paspaloides. Plant Physiol. 78: 844-848.

J a h n ke E., L i b be r t E., 1964. Indol-3-essigsäure als inziges Auxin bei Chara - Arten. Ztschr. Bot. 52: 283-284.

Je n n ing s R.C., M c C o m b A.J., 1967. Gibberellin in red alga Hypnea musciformis. Nature 215: 872.

K a u fman P.B., Petering L.B., A d a m s P.A., 1969. Regulation of growth and cellular differentiation in developing Avena internodes by gibberellic acid and indole-3-acetic acid. Amer. J. Bot. 56: 918-927.

K a za wa H., Katsumi M., 1974. Auxin-gibberellin relationships in their effects on hypocotyl elongation of light-grown cucumber seedlings. II. Effect of $\mathrm{GA}_{3}$-protreatment on IAA-induced elongation. Plant Cell Physiol. 15: 307-314. 
K wiatkowska M., Godlewski M., 1980. Effect of gibberellic acid and AMO-1618 on the development of vegetative systems in generatively maturated thalli of Chara vulgaris L. Acta Soc. Bot. Pol. 49: 445-458.

K wi a t k ow sk a M., G od lew sk i M., 1988. Studies on the role of gibberellins in the regulation of spermatogenesis in Chara vulgaris L. Acta Soc. Bot. Pol. 57: 547-553.

Lang A., 1970. Gibberellins: Structure and metabolism. Ann. Rev. Plant Physiol. 21: 537-570.

La n tica n B.P., M u ir R.M., 1969. Auxin physiology of dwarfism in Pisum sativum. Physiol. Plant. 22: 412-423.

L a w D.M., H a m ilt o n R.H., 1984. Effects of gibberellic acid on endogenous indole-3-acetic acid and indoleacetylaspartic acid level in a dwarf pea. Plant Physiol. 75: 255-256.

L a w D.M., H a milt on R.H., 1989. Reduction in the free indole-3-acetic acid levels in Alaska pea by the gibberellin biosynthesis inhibitor uniconazol. Physiol. Plant. 76: 535-538.

Maheshwari R., Shailini C., Veluthambi K., M ah a devan S., 1980. Interreaction of gibberellic acid and indole-3-acetic acid in the growth of excised Cuscuta shoots tips in vitro. Plant Physiol. 65: 186-192.

M ow at J.A., 1963. Gibberellin-like substances in algae. Nature 203: 453.

M u ra k a mi Y., 1966. Bioassay of gibberellins using rice endosperm and some problems of its application. Bot. Mag. (Tokyo) 79: 315-327.

Nair N.G., Kartha K.K., Gamborg O.L., 1979. Effect of growth regulators on plant regeneration from shoot apical meristems of cassava (Manihot exculenta Crantz) and on the culture of internodes in vitro. Z. Pflanzenphysiol. 95: 51-56.

P icket t - H e a p s J.D., 1967a. Ultrastructure and differentiation in Chara sp. I. Vegetative cells. Austr. J. Biol. Sci. 20: 539-551.

P icke t t- Hea ps J.D., 1967b. Ultrastructure and differentiation in Chara sp. III. Formation of the antheridium. Austr. J. Biol. Sci. 21: 255-274.

Radle y M., 1961. Gibberellin-like substances in plants. Nature 191: 684.

Shen E., 1967a. Microspectrophotometric analysis of nuclear DNA in Chara zeylandica. J. Cell. Biol. 35: 377-382.

Shen E., 1967b. Amitosis in Chara. Cytologia 32: 481-499.

Skoog F., Mille r C.O., 1957. Chemical regulation of growth and organ formation in plant tissues cultured in vitro. Symp. Soc. Exp. Biol. 11: 118-130.

Starling M.B., Chapman V.J., Brown J.M.A., 1974. A contribution to the biology of Nitella hookeri A.Br. in the Rotorua lakes, New Zealand. II. Organic nutrients and physical factors. Hydrobiologia 45: 157-168.

\section{Wplyw $\mathrm{GA}_{3}$, IAA i ich mieszaniny na rozwój wegetatywnej części plechy i organów generatywnych Chara vulgaris $L$.}

\section{Streszczenie}

IAA stosowany w zakresie stężeń od $10^{-7}$ do $10^{-5} \mathrm{M}$ wyraźnie stymuluje wzrost komórek międzywęźli nibyłodygi i pleuridiów, nie wpływa na liczbę odgałęzień bocznych plechy i liczbę organów rozmnażania, wydłuża czas spermatogenezy, a w większych stężeniach redukuje liczbę spermatozoidów tworzonych w anteridiach. $\mathrm{GA}_{3}$ w stosowanych stężèniach $10^{-7}-10^{-5} \mathrm{M}$ hamuje wzrost komórek międzywęźli, nibyłodygi i pleuridiów, nie wpływa na liczbę odgałęzień bocznych plechy, zwiększa liczbę anteridiów i przyspiesza ich rozwój oraz zwiększa liczbę tworzonych spermatozoidów. Inkubacje w mieszaninach obu regulatorów wzrostu wykazały, że: a) IAA znosi hamujący wpływ $\mathrm{Ga}_{3}$ na wzrost komórek międzywęźli nibyłodygi, a jego stymulujące działanie jest nieco osłabiane przez $\mathrm{GA}_{3}$; b) stosowany w stężeniu $10^{-5} \mathrm{M}$, przy niskim stężeniu $\mathrm{GA}_{3}\left(10^{-7} \mathrm{M}\right)$, zwiększa liczbę odgałęzień bocznych plechy; c) IAA w obecności $\mathrm{GA}_{3}$ powoduje przedłużenie czasu 
spermatogenezy nie modyfikując korzystnego wpływu $\mathrm{GA}_{3}$ na liczbę anterydiów i liczbę tworzonych spermatozoidów oraz wzmacnia wpływ $\mathrm{GA}_{3}$ na liczbę powstających oogoniów.

$\mathrm{W}$ poprzednich badaniach prowadzonych na Chara vulgaris inkubacja $w$ antygiberelinie (AMO-1618) powodowała stymulację wzrostu plechy i zmniejszenie liczby plemników tworzonych przez anterydia. Obniżenie poziomu gibereliny powoduje więc analogiczny efekt do uzyskanego obecnie po stosowaniu IAA. Wyniki tych badań potwierdzają wniosek, że wzrost wegetatywnej części plechy jest bujniejszy przy przewadze auksyny, natomiast rozwój generatywny wymaga wysokiego poziomu gibereliny. Wskazują też na istotne znaczenie nie tylko zawartości, ale i odpowiednich ilościowych proporcji między zawartością auksyny i gibereliny na różnych etapach morfogenezy plechy Chara vulgaris. 